\title{
Efforts to Increase the Pedagogics of Teachers in Making IT-Based Learning Media in the 4.0 Era
}

\author{
Yohanes Joko Winarto \\ Department of Education Management \\ Universitas Negeri Surabaya \\ Surabaya, Indonesia \\ yohanes.jokowinarto@yahoo.com
}

\begin{abstract}
This study aims to determine the pedagogical competence of teachers in learning, especially in making learning media. To achieve this goal, this study uses a qualitative approach. Data analysis procedures are data reduction, data display, and verification. While the research subjects were wakakur and teachers. The results of the study show that: (1) Teacher's pedagogical competence in the use of instructional media is still not good and has not increased student motivation in attending the lesson; and (2) Teacher's pedagogic competence in increasing student learning motivation is done by giving students the opportunity to be actively involved in using information and communication technology facilities in achieving learning goals, communicating effectively with students, and taking reflective actions to improve the quality of learning.
\end{abstract}

Keywords—teacher's pedagogic ability; learning media; industrial revolution 4.0

\section{INTRODUCTION}

According to the Academic Qualifications and Teacher Competence Standards [1], the types of competencies that must be possessed by teachers include pedagogical, personality, professional and social competencies obtained through professional education. Of the four teacher competencies it turns out that the pedagogical competence of the teacher occupies the most important place in education in general and in the implementation of learning because the teacher plays a very important role in the process. Where the learning process is at the core of the overall education process which involves aspects of teacher competence. In this case states that learning is understood as trying or practicing in order to get intelligence. In its implementation learning is an individual activity to gain knowledge of behavior and skills by processing teaching materials.

Based on the statement above, it can be understood that learning activities require practice and training to gain experience, with that experience that a person can be trained in realizing a special skill. To assemble a perfect learning experience should be in the teaching and learning process involving the functions and uses of learning methods, learning media, evaluation techniques, regional/regional characteristics, student characteristics, parental awareness, student motivation, occasion and opportunities to teach teachers and so on.

The main problem in our education is the low performance of teachers. The performance of our teachers is very low in learning management, and less professional in carrying out their profession as educational staff. This can be identified with the minimum fulfillment of academic qualifications, low basic skills of teachers, lack of competency in developing learning and curriculum, and low performance in learning activities [2].

According to constructivism learning theory from Vigotsky states that learning focuses on interaction with the social environment as a facilitator in learning. In this case the social environment such as the teacher is only a facilitator and student guide in learning [3]. The process and results of student learning are not only determined by the school, the pattern, structure, and content of the curriculum, but also largely determined by the competence of the teacher who teaches and guides them. Competent teachers will be better able to create an effective learning environment and will be better able to manage their classes so that student learning outcomes are at an optimal level.

Learning media is a tool or learning resource that can facilitate the learning process. The choice of learning media must consider to the characteristics and needs of students, especially in primary school-aged children who are still in the concrete operational stage. Apart from that, the development of learning media also requires a review of the effectiveness of the media, because good media doesn't need to be expensive but can fulfill the achievement of the learning process objectives.

The industrial revolution 4.0 has fundamentally changed human life and work. Unlike the previous industrial revolution, this 4th generation industrial revolution has a wider scale, scope and complexity. The advancement of new technologies that integrate the physical, digital and biological worlds has influenced all scientific, economic, industrial and government disciplines.

From the value of class supervision it is known that the value of media use in learning gets the lowest value from the 
average of all teachers. So the purpose of this study is to improve the pedagogical abilities of teachers in making ITbased learning media facing the era of industrial revolution 4.0.

\section{A. Teacher's Pedagogic Competence}

Competence is the ability or skill [4] to show responsibly to the tasks correctly. One way to improve the quality of education is to strengthen teacher competencies so that all their potential can be maximized [5].

According to the Government Regulation on Teachers [6], teacher pedagogical competence is the ability of teachers in managing of learning of students which at least includes: Understanding of insight or educational foundation, Understanding of students, Development of curriculum / syllabus, Learning design, Implementation of educational and dialogical learning, Utilization of learning technology, Evaluation of learning outcomes, Development of students to actualize their various potentials

\section{B. Instructional Media}

Asyhar [7] says that learning media can be understood as everything that can convey or channel messages from a planned source, so that a conducive learning atmosphere occurs where the recipient can carry out the learning process efficiently and effectively. Hamalik [8] argues that the function of learning media, namely:

a) To realize effective learning situations

b) The use of media is an integral part of the learning system

c) Learning media is very important in order to achieve learning goals

d) The use of media in learning is to accelerate the learning process and help students in an effort to understand the material presented by the teacher in the classroom

e) The use of learning media is intended to enhance the quality of education

According to Sudjana [9], the benefits of learning media for students are:

a) Teaching will attract students' attention so that it can foster learning motivation

b) The teaching material will be more clearly defined so that it can be better understood by students

c) The method of teaching will be more varied, not merely verbal communication by the teacher so students are not bored

d) Students do more learning activities, because they not only listen to lectures but also do other activities.

\section{4.0 Industrial Revolution}

Industrial Revolution 4.0 is one of the implementation of the modern German technology strategy project 2020 [10]. The strategy is implemented through increasing the technology of the manufacturing sector (industry), the creation of a consistent strategic policy framework, as well as setting certain priorities in the face of global competition.

Education 4.0 is a phenomenon that responds to the need for a fourth industrial revolution in which humans and machines are aligned to find solutions, solve problems and of course find the possibility of new innovations. Basic education to higher education, adjusting the education curriculum with challenges and needs in the current era. A curriculum that opens access for millennials to gain knowledge and training to become competitive and productive workers.

Talking about the issue of industrial revolution 4.0 and its relation to education, of course, the world of education is the main and central thing to follow the flow of this industrial revolution because it will print and produce quality generations that will fill in the 4.0 industrial revolution. Education in the era of industrial revolution 4.0 took the form of changes in the way of learning, thinking patterns and in the way students act to develop creative innovations in various fields of knowledge.

\section{METHOD}

This study uses a survey method. This method is considered appropriate because this research was conducted by collecting factual information through the use of questionnaires to test hypotheses. Respondents in this study were all teachers at SD (elementary school) Santo Joseph Surabaya with 18 respondents. Technical data analysis used is simple regression and product moment correlation. Data collection instrument in the form of a Likert scale model questionnaire consisting of two parts. The first part consisting of 38 items is a questionnaire to measure respondents' perceptions of teacher pedagogical competencies outlined from 10 components. The second part is a questionnaire to measure respondents' perceptions of the type of development of competencies that they need in their professional duties as teachers.

\section{RESULTS AND DISCUSSION}

TABLE I. TEACHER PEDAGOGIC COMPETENCE

\begin{tabular}{|c|l|c|c|}
\hline Number & Organizing educational learning. & Average & Value \\
\hline 1. & $\begin{array}{l}\text { Understand the principles of } \\
\text { educational learning design. }\end{array}$ & 3,06 & 76 \\
\hline 2. & $\begin{array}{l}\text { Develop components of learning } \\
\text { design. }\end{array}$ & 3,06 & 76 \\
\hline 3. & $\begin{array}{l}\text { Compile a complete learning plan, } \\
\text { both for activities in the classroom, } \\
\text { laboratory, and field. }\end{array}$ & 3,00 & 75 \\
\hline 4. & $\begin{array}{l}\text { Carry out learning that educates in } \\
\text { the classroom, in the laboratory, and } \\
\text { in the field. }\end{array}$ & 3,00 & 75 \\
\hline 5. & $\begin{array}{l}\text { Using learning media in accordance } \\
\text { with the characteristics of students } \\
\text { and five elementary subjects to } \\
\text { achieve the learning objectives as a } \\
\text { whole. }\end{array}$ & 1,94 & 75 \\
\hline 6. & $\begin{array}{l}\text { Take transactional decisions in five } \\
\text { elementary / MI subjects according } \\
\text { to the developing situation. }\end{array}$ & 3,00 & 75 \\
\hline
\end{tabular}

From the results of the pedagogic competency checklist of 18 teachers, it shows that the value of the indicator is about: Using learning media in accordance with the characteristics of 
students and five elementary subjects to achieve the learning objectives as a whole, is getting the lowest average compared to the average score of the other teachers' pedagogical competency indicators which are 1.94 and the acquisition of values is 49 . From these results indicate that teachers need to get training in using learning media.

Results of teacher checklists who desire training in making learning media $=$ There are as many as 15 teachers who want training to use learning media from 18 teachers, which percentage is $83.33 \%$. It turned out that as many as 15 teachers wanted to get training in the use of learning media with a percentage of $83.33 \%$. From the results of table 1 and 2 data, it can be desiring that the teachers at SD (elementary school) Santo Yosef Surabaya desiring training in making learning media in improving their pedagogical competencies. Competencies needed in the education era 4.0 are:

First, critical thinking skills and problem solving (critical thinking and problem solving skills). This competency is very important for students in 21 st century learning. Teacher 4.0 must be able to mix learning so that they can explore these competencies from the students themselves.

Second, communication and collaborative skills (communication and collaborative skills). As one of the competencies that are urgently needed in the 21 st century, these skills must be able to be constructed in learning. Information and communication technology-based learning models must be applied by teachers to construct communication and collaboration competencies.

Third, creative thinking skills and innovation (creativity and innovative skills). The industrial revolution 4.0 requires students to always think and act creatively and innovatively. This action needs to be done so that students are able to compete and create industry-based employment 4.0. This condition is necessary considering that there has been a lot of impact from the industrial revolution 4.0. For example, many professions are replaced by digital robot machines. For example, payment of toll roads uses e-toll. This system has forced toll road managers to dismiss workers who have been used at each toll gate.

Fourth, literacy of information and communication technology (information and communication technology literacy). Information and communication technology literacy (ICT) is an obligation for teachers 4.0. ICT literacy must be done so as not to be left behind by students. ICT Literacy is the basis that must be mastered by teacher 4.0 in order to be able to produce students who are ready to compete in the face of the 4.0 industrial revolution.

Fifth, contextual learning skills. Contextual learning is very suitable learning applied by teacher 4.0. If the teacher has mastered ICT literacy, then the 4.0 education era contextual learning is easier to do. The current condition of ICT is one of the contextual concepts that must be recognized by the teacher. Learning material is much contextually ICT-based so that teacher 4.0 is very unprepared if it does not have ICT literacy. Difficult material that is abstract in nature can be presented to be more real and contextual using ICT.
Sixth, information and media literacy (information and media literacy). Many media information is social that is liked by students. Social media seems to be a powerful communication medium used by students and teachers. Social media is one of the learning media that can be used by teachers 4.0. The presence of digital classes that are social media can be used by teachers, so that learning takes place without limits of space and time.

Teachers must be prepared to face the era of education 4.0 even though they are preoccupied with a very heavy curriculum and administrative burden. If not, then our young generation will continue to lag behind and the effect will not be able to compete against the implications of the Industrial Revolution 4.0 .

\section{CONCLUSION}

Based on the explanation above, the authors conclude that in the face of this Industrial Revolution 4.0 era, Principals must be able to improve the quality of education by selfdevelopment and good management of education. Therefore, the problem that needs attention is to improve the pedagogical competence of teachers in making learning media so that they are ready to face various changes in the field of education.

Facing the big challenges, education is required to change too. Including education at the level of primary and secondary education. The education era which was influenced by the 4.0 industrial revolution was called Education 4.0. Education 4.0 is an education characterized by the use of digital technology in the learning process or known as a cyber system. This system is able to make the learning process can take place continuously without space and time limits.

As the front guard in the world of education, teachers must upgrade competencies in the face of the era of Education 4.0. The students faced by teachers today are millennial generations who are no stranger to the digital world. Students are familiar with industrial information and technology 4.0. This shows that graduated school products must be able to answer the challenges of industry 4.0.

The education era 4.0 is the answer to the 4.0 industrial revolution. Teacher 4.0 is needed in facing the education era 4.0. How to become a teacher 4.0 ? This question is very important to be answered so that the teacher is able to improve competence towards teacher 4.0. Teacher 4.0 has a greater responsibility in educating students to face the 4.0 Industrial Revolution. Teacher 4.0 is a teacher who is able to master and utilize digital technology in learning.

\section{REFERENCES}

[1] P. M. P. N. R. Indonesia, "No. 16 Tahun 2007 tentang Standar Kualifikasi Akademik dan kompetensi guru, Dalam Buku Peraturan Menteri Pendidikan Nasional RI No. 16-17 dan 18 Tahun 2007 Tentang Standar Kualifikasi Guru dan Sertifikasi Bagi guru dalam jabatan.” Jakarta: CV Minijaya Abadi.

[2] Z. Hanapi and M. S. Nordin, "Unemployment among Malaysia graduates: Graduates' attributes, lecturers' competency and quality of education," Procedia-Social Behav. Sci., vol. 112, pp. 1056-1063, 2014.

[3] D. H. Schunk, Learning theories an educational perspective sixth edition. Pearson, 2012. 
[4] S. Muhibbin, "Psikologi pendidikan dengan pendekatan baru," Bandung PT Remaja Rosdakarya, 2010.

[5] R. Fernandez, "Teachers competence and learners performance in the alternative learning system towards, an enriched instructional program," Unpubl. Diss. Pamantasan ng Lungsod ng Maynila, Philipp., 2013.

[6] R. I. Mendiknas, "Peraturan Menteri Pendidikan Nasional RI No. 16 Tahun 2007 tentang Standar Kualifikasi Akademik dan Kompetensi Guru," Jakarta: Mendiknas, 2007.

[7] R. Asyhar, "Kreatif mengembangkan media pembelajaran." Jakarta: Referensi Jakarta, 2012.

[8] O. Hamalik, "Kurikulum pembelajaran," Jakarta Sinar Graf., 2008.

[9] N. Sudjana, "Penilaian hasil belajar mengajar," Bandung: Remaja Rosdakarya, 2009.

[10] A. Braun and A. Thielmann, "Country Report Germany," 2013. 